\title{
Genetic variability for nutritional quality in Lentil (Lens culinaris Medikus Subsp. culinaris)
}

\author{
Ashutosh Sarker ${ }^{1}$, Aqeel Hasan Rizvi*1 and Murari Singh ${ }^{2}$ \\ ICARDA South Asia and China Regional Program, \\ Office Block-C, NASC Complex, DPS Marg, New Delhi-110 012, India. \\ Received: 26-05-2017 Accepted: 11-09-2017
}

DOI: $10.18805 /$ LR-372

\begin{abstract}
Lentil (Lens culinaris Medikus Subsp. culinaris) is important dietary source of macro and micro-nutrients essential for human health. It provides essential amino acids to meet nutrient requirements. In order to develop macro/micro-nutrient rich lines, it is essential to know the level of genetic variability in the lentil accessions. A preliminary evaluation of seeds of 234 germplasm collected from various countries was carried out to understand the macro and micro-nutrient concentration level of phosphorus, potassium, calcium, magnesium, sulphur, iron, manganese, boron, copper and zinc which are essential nutrients for maintaining human health. Substantial variability of mineral concentration was estimated across the accessions. Highest seed concentrations (in mg kg${ }^{-1}$ ) were recorded in ILL8194 [P (5800); K (13600)], ILL8105 [Ca (1860)], ILL7200 [Mg (1300)], ILL6212 [S (3100)], ILL7547 [Fe (86)], ILL9886 [Mn (20)], ILL6459 [B (9.7)], ILL1005 [Cu (17)] and ILL5480 [Zn (60)]. Significant correlation was observed among the macro and micro-nutrients. Highest positive correlation was observed between $\mathrm{Ca}$ and $\mathrm{Mg}$ followed by $\mathrm{K}$ and $\mathrm{S}, \mathrm{P}$ and $\mathrm{K}$, and $\mathrm{Ca}$ and $\mathrm{B}$; and $\mathrm{K}$ showed higher negative correlation with $\mathrm{B}$ and $\mathrm{Ca}$. The high nutrient-content accessions identified in this study will be used as parents in developing nutritious lentils at ICARDA and by its cooperating national partner institutions.
\end{abstract}

Key words: Association, Correlation, Genetic variability, Lentil, Macro-nutrient, Micro-nutrient, Nutritional security.

\section{INTRODUCTION}

Lentil (Lens culinaris ssp. culinaris) is an ancient and early domesticated legume that continues to play an important role in human and animal diet, and modern agriculture. It is the fourth most important legume crop after bean (Phaseolus vulgaris L.), pea (Pisum sativum) and chickpea (Cicer arietinum); with an area of $4.17 \mathrm{~m}$ ha and production of $4.41 \mathrm{~m}$ tons in 2011 (FAO, 2013). Lentil is an important source of protein, fibre, minerals, vitamins, and antioxidant compounds and macronutrients, micronutrients and trace elements. Dietary deficiencies in mineral elements can have significant negative impacts, such as learning disabilities in children, increased morbidity and mortality etc. It has been estimated that nearly 3.7 billion people worldwide are Fe deficient and 54\% of these are severely deficient (Yang et al., 2007). Nutrient deficiencies mainly result from their low concentrations in most of the plant foods and thus in the daily diet. Hence, there has been an interest in increasing the mineral concentrations of various seed crops. With these intentions, breeding strategies have been devised for increasing macro and micro-nutrient density in foods and are being assessed to develop sustainable and longterm solutions.

Producing micronutrient-enriched cultivars, particularly those with increased $\mathrm{Zn}$ and Fe either agronomically or genetically and improving the bio availability of these minerals are considered a promising and cost effective method to manage micronutrient deficiencies. One approach that can be used to increase the level of mineral nutrients in food crops is to identify the sources of genetic diversity, screen for natural variants that have favourable traits and use these to develop new cultivars. Furthermore, the diversity in the lentil landraces has resulted due to differences in adaptability to traditional farming systems and taste preferences of the community in regions where lentil is cultivated.

In the present study, we examined the genetic variation in macronutrients $(\mathrm{P}, \mathrm{K}, \mathrm{Ca}, \mathrm{Mg}$ and $\mathrm{S})$ and micronutrients ( $\mathrm{Fe}, \mathrm{Mn}, \mathrm{B}, \mathrm{Cu}$ and $\mathrm{Zn}$ ) to identify germplasm that could be used to improve the nutritional quality of lentil and provide information to international breeders. With a view the present study was undertaken to assess the variability in the germplasm for the various nutrients. The objectives of this study was supported by Harvest-Plus, CGIAR to a) assess the variability in commonly used nutrients, b) distribution of macro and micro-nutrients and potential of the germplasm resources, c) correlation between these elements, d) similarities in accessions for these elements and variation between and within the clusters, and e) association between the clusters with the origin of germplasm collected. 


\section{MATERIALS AND METHODS}

Genetic material: Genetic material consisted of 234 lentil germplasm collected from various countries and breeding lines from ICARDA (Table 1). Breeding lines developed at International Center for Agricultural Research in the Dry Areas in an un-replicated completely randomized design, were derived from parents adapted to diverse traits. All these accessions were grown in an un-replicated single row plot of $4 \mathrm{~m}$ long and randomly allotted to a homogeneous field at the ICARDA Research station, Tel Hadya, Syria during 2006/ 07 cropping season.

Preparation for grain nutrient analysis: The seeds were harvested from each accession by selecting uniform 5 individual plants, bulk them and threshed. Harvested seed material were dried in sunlight and from each genotypes 6$8 \mathrm{~g}$ was sampled for grinding to make it powder. To avoid any contamination, gloves were used during grinding of the seeds. Biochemical analysis for grain macro and micronutrients was carried out in triplicate samples by digestion using 9:4 di-acid mixture $\left(\mathrm{HNO}_{3}: \mathrm{HClO}_{4}\right)$ followed by Atomic Absorption Spectrometry method using AAS (make) at Waite Institute, University of Adelaide, Australia as per protocol described by Zarcinas et al. (1987) and Singh et al. (2005).

Statistical analysis: The simple statistics on means, minimum, maximum, standard deviation and coefficient of variation $(\mathrm{CV})$ were obtained. The distribution of the nutrients was also examined and tested for their normality using non-parametric tests such as Anderson-Darling, Cramer von Mises and Waston (Aitchison 1986). Association between various nutrients was assessed using simple correlation coefficient. The interrelationship between the accessions, for a given nutrient, was obtained using hierarchical clustering based on Euclidean distance between the accessions. The average link method, also known as UPGMA(Unweighted Pair Group Method with Arithmetic mean), was used to generate the clusters. Statistical significance of separation between the cluster means was assessed using within cluster variation in a one-way analysis of variance. Various computations were performed in Genstat software (Payne 2011) environment.

\section{RESULTS AND DISCUSSION}

Variability of macro and micro-nutrients: In current study, status of macro and micro-nutrient in seeds of 234 lentil germplasm lines including breeding lines from ICARDA and germplasm from different countries were studied (Table 1). Seeds were analysed for 10 important macro and micronutrients namely Phosphorus (P), Potassium (K), Calcium (Ca), Magnesium (Mg), Sulphur (S), Iron (Fe), Manganese (Mn), Boron (B), Copper (Cu) and Zinc (Zn). Table 2 shows the mean, maximum and minimum of all the analyzed mineral

Table 1: Distribution of plant material by origin

\begin{tabular}{|c|c|c|}
\hline \multicolumn{2}{|c|}{ No. of genotypes } & ICARDA/International Lentil Line (ILL) numbers \\
\hline $\begin{array}{l}\text { Breeding Line, } \\
\text { ICARDA, Syria }\end{array}$ & 126 & $\begin{array}{l}7657,7670,7686,7690,7701,7706,7949,7950,7960,7961,7972,8006,8074,8077, \\
8090,8138,8140,8176,8189,8194,8195,8604,8605,8606,8618,8621,8623,8627, \\
9830,9832,9837,9838,9839,9840,9841,9842,9843,9844,9845,9846,9847,9848, \\
9849,9850,9854,9858,9859,9860,9861,9862,9864,9867,9870,9873,9877,9878, \\
9885,9886,9887,9888,9897,9898,9899,9900,9901,9902,9903,9904,9905,9906, \\
9907,9908,9909,9910,9911,9912,9913,9914,9915,9916,9917,9918,9919,9920, \\
9921,9922,9923,9924,9925,9926,9927,9928,9929,9930,9931,9932,9933,9934, \\
9935,9936,9937,9938,9939,9940,9942,9944,9945,9947,9948,9950,9951,7668, \\
7678,7685,7940,7941,7947,8008,9833,9889,9890,9891,9892,9893,9894,9895\end{array}$ \\
\hline Syria & 48 & $\begin{array}{l}5684,5715,5722,5725,5755,5782,6004,6024,6031,6212,6238,6243,6246,6258, \\
6467,6811,6821,6994,7127,7193,7199,7201,7204,7502,7504,7517,7521,7537, \\
7979,7980,4400,5597,5748,5823,6002,6025,6027,6199,6207,6211,6459,6465, \\
6972,6980,6982,7177,7200,7978\end{array}$ \\
\hline Jordan (JOR) & 11 & $5588,5883,7982,7983,8095,5244,5582,7985,7991,8091,8093$ \\
\hline Chile (CHL) & 5 & $2313,5540,465,780,1005,1851$ \\
\hline Nepal (NPL) & 5 & $7207,7215,7219,7213,7217$ \\
\hline Pakistan (PAK) & 5 & $4402,7616,7617,7618,7620,9836$ \\
\hline Turkey (TUR) & 5 & $590,8173,1878,8612,8634$ \\
\hline Morocco (MAR) & 4 & $96,7711,7553,7558$ \\
\hline Argentina (ARG) & 4 & $4605,8108,8109$ \\
\hline Egypt (EGY) & 3 & $784,818,813$ \\
\hline Bangladesh (BGD) & 2 & 7713,7717 \\
\hline Canada $(\mathrm{CAN})$ & 2 & 8105,8106 \\
\hline Algeria (DZA) & 2 & 857,7547 \\
\hline USA & 2 & 8174,9896 \\
\hline Ten countries & 1 (each) & $\begin{array}{l}6408 \text { (Bulgaria/BGR), } 5480 \text { (Czechoslovakia/CSK), } 7981 \text { (Ecuador/ECU), } 2439 \\
\text { (Ethiopia/ETH), } 7543 \text { (India/IND), } 759 \text { (Iran/IRN), } 358 \text { (Mexico/MEX), } 4606 \\
\text { (Palestine/PAL), } 6829 \text { (Poland/POL), } 323 \text { (Serbia/SRB) }\end{array}$ \\
\hline Total & 234 & \\
\hline
\end{tabular}


nutrients in 234 germplasm lines. The studied germplasm showed considerable variation in mineral levels (Table 2). The top five lines for each macro and micro-nutrients are listed in Table 3. Correlations among the macro and micronutrients present in the germplasm are presented in Table 4. Bar Chart representing nutrient wise frequency distribution in all the germplasm studied (Figure 1). The variation between the cluster means was found statistically significant $(\mathrm{P}<0.001)$ (Table 5). The distributions of lines in various clusters are given in Table 6 along with basic statistics.

Macronutrients: Mean P content of germplasm was 4239 $\mathrm{mg} \mathrm{kg}-1$ and ranged from 3000 to $5800 \mathrm{mg} \mathrm{kg}^{-1}$ (Table 2). The genotypes viz. ILL 8194, ILL 7978 and ILL 784 had the highest while ILL 8612, ILL9908, ILL 9900 and ILL 9899 had the lowest $\mathrm{P}$ levels. The mean $\mathrm{K}$ and $\mathrm{Ca}$ concentrations of the germplasm are $10795 \mathrm{mg} \mathrm{kg}^{-1}$ (range: 8600 to $13600 \mathrm{mg} \mathrm{kg}^{-1}$ ) and $410.9 \mathrm{mg} \mathrm{kg}^{-1}$ (range: 189.9 to $1860 \mathrm{mg} \mathrm{kg}^{-1}$ ), respectively. The genotypes viz. ILL 8194, ILL, 590 and ILL 6002 had the highest while and ILL 9899 and ILL 9900 had the lowest K levels. The genotype ILL 8105 had the highest while the genotypes ILL 7686 and ILL 5480 had lowest levels of $\mathrm{Ca}$. The mean level of $\mathrm{Mg}$ was $969.7 \mathrm{mg} \mathrm{kg}^{-1}$ for all the germplasm lines. Its level ranges from 700 to $1300 \mathrm{mg} \mathrm{kg}^{-1}$. The genotypes ILL7200 and ILL 7553 had highest while the genotypes viz. ILL 7207, ILL7686 and ILL 5755 had lowest level of Mg. The mean S concentration of 234 lines was 2278 $\mathrm{mg} \mathrm{kg}^{-1}$. It ranged from 1790 to $3100 \mathrm{mg} \mathrm{kg}^{-1}$. The line ILL
6212 had the highest and the lines ILL 780, ILL 8612 had shown the lowest $S$ level.

Micronutrients: In the studied germplasm lines, the amount of Fe varied from 40.54 to $81.39 \mathrm{mg} \mathrm{kg}^{-1}$, and the mean was $66.40 \mathrm{mg} \mathrm{kg}^{-1}$. The lines ILL 7547, ILL 1878 and ILL 7668 were shown the highest Fe levels and the lines ILL 9848 and ILL 9951 recorded the lowest Fe levels (Table 3). Mean Mn concentration of all germplasm lines was $13.7 \mathrm{mg} \mathrm{kg}^{-1}$ and its concentration level was ranged from 9.25 to $20.29 \mathrm{mg}$ $\mathrm{kg}^{-1}$. The lines ILL 9886, ILL 8195 and ILL 590 have the highest Mn levels and ILL 4605 and ILL 5715 had the lowest Mn levels. The concentration of B varied from 3.62 to 9.67 $\mathrm{mg} \mathrm{kg}^{-1}$. The lines ILL 6459, ILL 4402 and ILL 8105 have found with the highest levels of B; and the lines ILL 9841, ILL 9936, ILL 5588 showed the lowest B levels. The mean of $\mathrm{Cu}$ concentration level recorded was $12.27 \mathrm{mg} \mathrm{kg}^{-1}$ for all germplasm. It ranged from 7.46 to $17.33 \mathrm{mg} \mathrm{kg}^{-1}$. The lines ILL 1005, ILL 7678 and ILL 7127 recorded the highest levels of $\mathrm{Cu}$ and the lines ILL 7177 and ILL 358 showed the lowest levels of $\mathrm{Cu}$. The average $\mathrm{Zn}$ concentration of the all 234 germplasm lines studied was $44.98 \mathrm{mg} \mathrm{kg}^{-1}$ and the range was 22.36 to $60.40 \mathrm{mg} \mathrm{kg}^{-1}$. The germplasm lines ILL 5480, ILL 9888, ILL 6211 and ILL 5725 are found with the highest Zn levels; and the lines ILL 9945, ILL 5722 and ILL 5540 with lowest $\mathrm{Zn}$ levels.

Frequency distribution of 234 lentil germplasm for grain concentration of all ten nutrients viz., $\mathrm{P}, \mathrm{K}, \mathrm{Ca}, \mathrm{Mg}, \mathrm{S}$,

Table 2: Mean, standard deviation, minimum and maximum, and CV of macro and micro-nutrients in the lentil collection (N=234)

\begin{tabular}{|c|c|c|c|c|c|}
\hline Variable $^{@}\left(\mathrm{mg} \mathrm{kg}^{-1}\right)$ & Mean & Standard Deviation & Minimum & Maximum & CV (\%) \\
\hline $\mathbf{P}$ & 4239 & 594.2 & 3000 & 5800 & 14.0 \\
\hline $\mathbf{K}$ & 10795 & 884.9 & 8600 & 13600 & 8.2 \\
\hline $\mathbf{C a}$ & 410.9 & 219.4 & 189.9 & 1860 & 53.4 \\
\hline Mg & 969.7 & 118.8 & 700 & 1300 & 12.3 \\
\hline $\mathbf{S}$ & 2278 & 196.3 & 1790 & 3100 & 8.6 \\
\hline $\mathbf{F e}$ & 66.40 & 5.834 & 40.54 & 85.61 & 8.8 \\
\hline Mn & 13.70 & 1.835 & 9.251 & 20.29 & 13.4 \\
\hline B & 5.361 & 1.284 & 3.623 & 9.665 & 24.0 \\
\hline $\mathbf{C u}$ & 12.27 & 1.351 & 7.458 & 17.33 & 11.0 \\
\hline$\underline{Z n}$ & 44.98 & 6.642 & 22.36 & 60.40 & 14.8 \\
\hline
\end{tabular}

${ }^{\circledR}$ Based on common tests for normality, Anderson-Darling, Cramer von Mises and Waston, $\mathrm{Cu}$ was normally distributed while other micro-nutrients departed significantly $(\mathrm{P}<0.05)$ from the normal distribution.

Table 3: Top five accessions containing high values for macro and micro-nutrients from 234 lines

\begin{tabular}{|c|c|c|c|c|c|}
\hline \multirow{2}{*}{$\begin{array}{l}\text { Nutrients } \\
\text { Concentration }\end{array}$} & \multicolumn{5}{|c|}{ Name of Accessions (Rank wise) } \\
\hline & 1 & 2 & $\mathbf{3}$ & 4 & 5 \\
\hline$\overline{\mathbf{P}\left(\mathrm{mg} \mathrm{kg}^{-1}\right)}$ & ILL8194(5800) & ILL7978(5600) & ILL784(5600) & ILL9877(5500) & ILL7200(5500) \\
\hline K(mg kg $\left.{ }^{-1}\right)$ & ILL8194(13600) & ILL590(13300) & ILL6002(13100) & ILL6212(12900) & ILL9930(12800) \\
\hline $\mathrm{Ca}\left(\mathrm{mg} \mathrm{kg}{ }^{-1}\right)$ & ILL8105(1860) & ILL6980(1060) & ILL7200(970) & ILL813(960) & ILL7213(940) \\
\hline $\operatorname{Mg}\left(\mathbf{m g ~ k g}{ }^{-1}\right)$ & ILL7200(1300) & ILL7553(1270) & ILL6211(1240) & ILL6980(1230) & ILL7685(1220) \\
\hline $\mathrm{S}\left(\mathrm{mg} \mathrm{kg}^{-1}\right)$ & ILL6212(3100) & ILL6238(2800) & ILL9940(2700) & $\operatorname{ILL6027(2700)}$ & ILL5540(2700) \\
\hline $\mathrm{Fe}\left(\mathrm{mg} \mathrm{kg}^{-1}\right)$ & ILL7547(85.61) & ILL1878(83.44) & ILL7668(81.78) & ILL9892(80.83) & ILL7558(79.76) \\
\hline $\operatorname{Mn}\left(\mathbf{m g ~ k g}{ }^{-1}\right)$ & ILL9886(20.29) & ILL8195(19.03) & ILL590(18.97) & ILL6024(18.61) & ILL7204(18.53) \\
\hline B(mg kg-1) & ILL6459(9.67) & ILL4402(9.66) & ILL8105(9.31) & ILL4605(8.99) & ILL8093(8.64) \\
\hline $\mathrm{Cu}\left(\mathrm{mg} \mathrm{kg} \mathrm{kg}^{-1}\right)$ & ILL1005(17.33) & ILL7678(15.79) & ILL7127(15.67) & ILL9892(15.19) & ILL9910(15.09) \\
\hline $\mathrm{Zn}\left(\mathrm{mg} \mathrm{kg}{ }^{-1}\right)$ & ILL5480(60.40) & ILL9888(60.35) & ILL6211(59.00) & ILL5725(58.95) & ILL96(57.51) \\
\hline
\end{tabular}


Table 4: Correlation among the macro and micro-nutrient based on the $\mathrm{N}=234$ lentil accessions

\begin{tabular}{|c|c|c|c|c|c|c|c|c|c|c|}
\hline Variables & $\mathbf{P}$ & $\mathbf{K}$ & $\mathbf{C a}$ & Mg & $\mathbf{S}$ & $\mathbf{F e}$ & Mn & B & $\mathbf{C u}$ & $\mathbf{Z n}$ \\
\hline$\overline{\mathbf{P}}$ & - & & & & & & & & & \\
\hline $\mathbf{K}$ & 0.61 & - & & & & & & & & \\
\hline $\mathbf{C a}$ & 0.27 & $-0.13^{* *}$ & - & & & & & & & \\
\hline Mg & 0.57 & $0.19 * *$ & 0.77 & - & & & & & & \\
\hline $\mathbf{S}$ & 0.55 & 0.70 & -0.03 & 0.22 & - & & & & & \\
\hline $\mathbf{F e}$ & $0.09 *$ & $0.10 *$ & 0.35 & 0.36 & $0.13 * *$ & - & & & & \\
\hline Mn & 0.31 & 0.40 & $0.06^{*}$ & $0.09 *$ & 0.28 & 0.04 & - & & & \\
\hline B & 0.23 & $-0.15 * *$ & 0.59 & 0.51 & $-0.11 *$ & $0.14 *$ & $-0.07 *$ & - & & \\
\hline $\mathrm{Cu}$ & 0.30 & 0.39 & 0.01 & 0.23 & 0.40 & 0.34 & $0.13 * *$ & $-0.07 *$ & - & \\
\hline Zn & 0.57 & 0.52 & $0.17 * *$ & 0.39 & 0.54 & 0.34 & 0.27 & 0.01 & 0.54 & - \\
\hline
\end{tabular}

Significance: $* * *$ and the values in bold indicate statistical significance at $5 \%, 1 \%$ and $0.1 \%$ respectively. All other estimates were non-significant $(\mathrm{P}>0.05)$
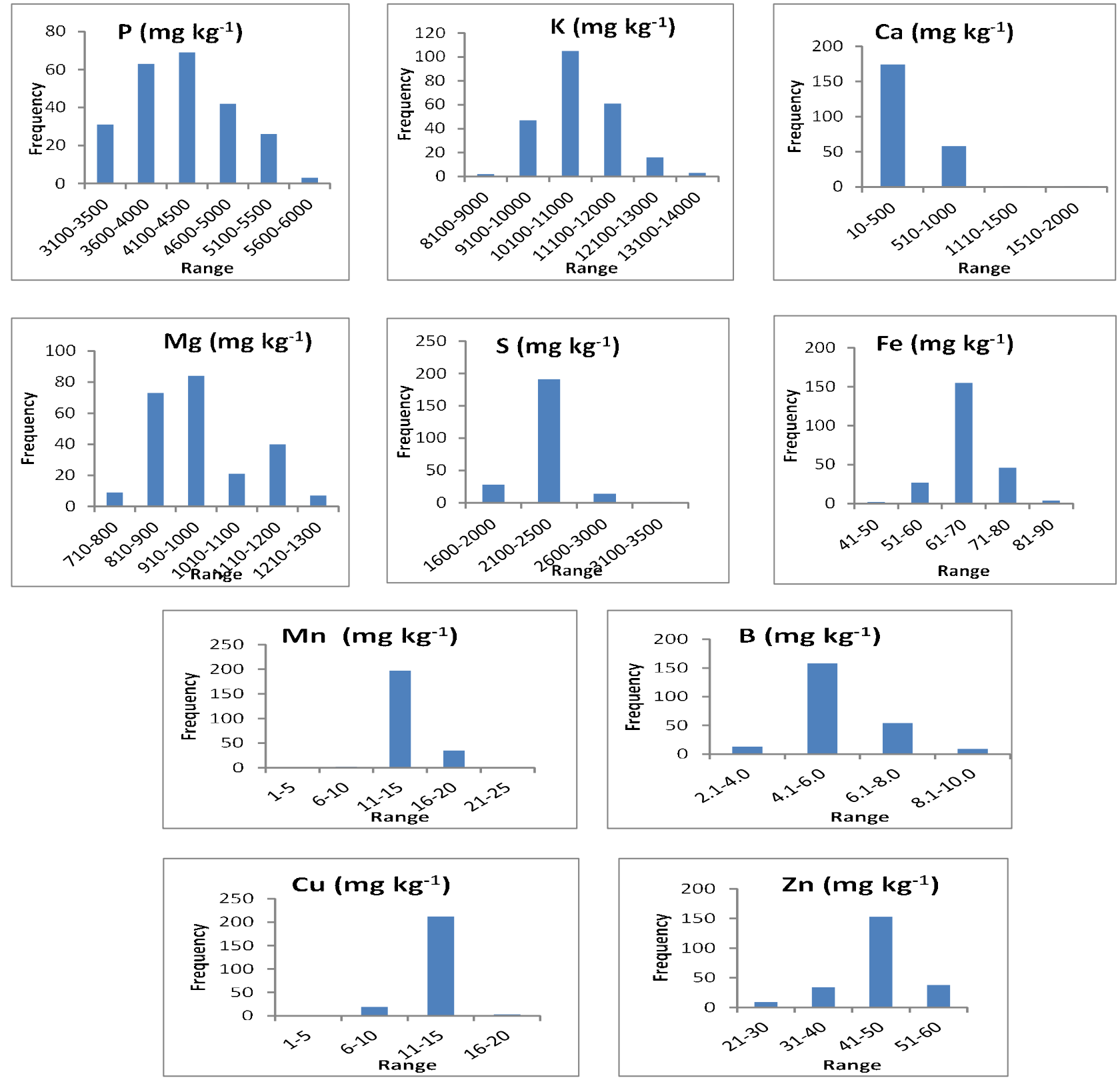

Fig-1: Histograms of the macro and micro-nutrients as observed in 234 lines of lentil 
$\mathrm{Fe}, \mathrm{Mn}, \mathrm{B}, \mathrm{Cu}$ and $\mathrm{Zn}$ showed bell shaped curves except in Ca which is positively skewed (Right skewed). (Figure 1). The distributions of each element, except $\mathrm{Cu}$, were statistically different $(\mathrm{P}<0.05)$ from normal as indicated by each of the three tests viz., Anderson-Darling, Cramer- von Misses and Watson (Aitchison, 1986).

Correlation among macro and micro-nutrients: Significant correlation was observed among the macro and micronutrients at $\mathrm{P}<0.05$ or higher probability (Table 4$)$. It was positively significant and highest in $\mathrm{Ca}$ and $\mathrm{Mg}(0.77)$ followed by $\mathrm{K}$ and $\mathrm{S}(0.70), \mathrm{P}$ and $\mathrm{K}(0.61)$, and $\mathrm{Ca}$ and $\mathrm{B}$ (0.59). The $K$ showed significant and higher negative correlation with $\mathrm{B}(-0.15)$ and $\mathrm{Ca}(-0.13)$. The significant and positive correlation of $\mathrm{P}$ was also observed with $\mathrm{Mg}$ (0.57), $\mathrm{Zn}(0.57)$ and $\mathrm{S}(0.55)$. The $\mathrm{Zn}$ also had positively significant correlation with $\mathrm{K}(0.52), \mathrm{S}(0.54)$ and $\mathrm{Cu}(0.54)$. Similarly, $\mathrm{Mg}$ had positive and significant correlation with $\mathrm{B}(0.51)$.

Similarity of lines for the macro and micro-nutrients: Based on the hierarchical cluster analysis, similarity groups of lines were identified for each macro/micro-nutrient at $90 \%$ similarity (Table 5). For each element, except Mg, the 234 lines were found grouped into three clusters, while for $\mathrm{Mg}$
Table 5: Extent of variability between the clusters mean relative to the variability within the clusters in terms of variance ratio

\begin{tabular}{lcc}
\hline Variables & \multicolumn{2}{c}{ Clusters formed at 90\% } \\
\cline { 2 - 3 } & No. of clusters & variance ratio \\
\hline $\mathrm{P}$ & 3 & 553.92 \\
$\mathrm{~K}$ & 3 & 374.56 \\
$\mathrm{Ca}$ & 3 & 666.21 \\
$\mathrm{Mg}$ & 2 & 521 \\
$\mathrm{~S}$ & 3 & 101.2 \\
$\mathrm{Fe}$ & 3 & 154.65 \\
$\mathrm{Mn}$ & 3 & 351.56 \\
$\mathrm{~B}$ & 3 & 607.94 \\
$\mathrm{Cu}$ & 3 & 143.24 \\
$\mathrm{Zn}$ & 3 & 340.48 \\
\hline $\mathrm{P}-\mathrm{va}$
\end{tabular}

$\mathrm{P}$ - value observed for the between the clusters variance and within the clusters variance ratio was $<0.001$ for each of the nutrients.

into two. It gives between the group variance relative to the within the group as variance ratio (VR), which varied from 101 to 666. The highest VR was observed for Ca followed by $\mathrm{B}, \mathrm{P}, \mathrm{Mg}$ and $\mathrm{K}$.

For each cluster, distributions of the elements are given in Table 6. For most of the elements, within the cluster $\mathrm{CV}$ is reasonably low, e.g., $<10 \%$. However, there were a few clusters with a relatively larger variability, i.e., less

Table 6: Distribution of lines in various clusters, and the means, standard deviation, minimum and maximum of the clusters.

\begin{tabular}{|c|c|c|c|c|c|c|c|}
\hline \multirow{2}{*}{$\begin{array}{l}\begin{array}{l}\text { Variables } \\
\left(\mathrm{mg} \mathrm{kg}^{-1}\right)\end{array} \\
\end{array}$} & \multicolumn{6}{|c|}{ 90\% Similarity } & \multirow[b]{2}{*}{ Maximum } \\
\hline & Clusters & No. of lines & Mean & SD & $\mathrm{CV}(\%)$ & Minimum & \\
\hline \multirow[t]{3}{*}{$\mathrm{P}$} & 1 & 42 & 5167 & 218.3 & 4.2 & 4900 & 5800 \\
\hline & 2 & 127 & 4289 & 272.6 & 6.4 & 3900 & 4800 \\
\hline & 3 & 65 & 3542 & 212.1 & 6.0 & 3000 & 3800 \\
\hline \multirow[t]{3}{*}{ K } & 1 & 127 & 11065 & 417 & 3.8 & 10500 & 11900 \\
\hline & 2 & 24 & 12437 & 448 & 3.6 & 12000 & 13600 \\
\hline & 3 & 83 & 9907 & 448.2 & 4.5 & 8600 & 10400 \\
\hline \multirow[t]{3}{*}{$\mathrm{Ca}$} & 1 & 175 & 301.8 & 68.75 & 22.8 & 189.9 & 510 \\
\hline & 2 & 58 & 715.2 & 120.96 & 16.9 & 560 & 1060 \\
\hline & 3 & 1 & 1860 & $\mathrm{a}$ & $\mathrm{a}$ & 1860 & 1860 \\
\hline \multirow[t]{2}{*}{$\mathrm{Mg}$} & 1 & 142 & 890.4 & 49.98 & 5.6 & 700 & 960 \\
\hline & 2 & 92 & 1092.3 & 85.25 & 7.8 & 970 & 1300 \\
\hline \multirow[t]{3}{*}{ S } & 1 & 194 & 2220 & 153.9 & 6.9 & 1790 & 2400 \\
\hline & 2 & 39 & 2549 & 75.6 & 3.0 & 2500 & 2800 \\
\hline & 3 & 1 & 3100 & $\mathrm{a}$ & $\mathrm{a}$ & 3100 & 3100 \\
\hline \multirow[t]{3}{*}{$\mathrm{Fe}$} & 1 & 199 & 65.91 & 3.808 & 5.8 & 57.02 & 72.71 \\
\hline & 2 & 24 & 76.64 & 3.438 & 4.5 & 73.21 & 85.61 \\
\hline & 3 & 11 & 52.99 & 4.984 & 9.4 & 40.54 & 56.48 \\
\hline \multirow[t]{3}{*}{$\mathrm{Mn}$} & 1 & 158 & 12.69 & 0.9179 & 7.2 & 9.25 & 14.07 \\
\hline & 2 & 10 & 18.62 & 0.7055 & 3.8 & 17.86 & 20.29 \\
\hline & 3 & 66 & 15.38 & 0.9392 & 6.1 & 14.11 & 17.48 \\
\hline \multirow[t]{3}{*}{ B } & 1 & 164 & 4.639 & 0.5089 & 11.0 & 3.623 & 5.743 \\
\hline & 2 & 49 & 6.582 & 0.4362 & 6.6 & 5.82 & 7.364 \\
\hline & 3 & 21 & 8.156 & 0.7062 & 8.7 & 7.438 & 9.665 \\
\hline \multirow[t]{3}{*}{$\mathrm{Cu}$} & 1 & 196 & 12.28 & 0.9174 & 7.5 & 10.53 & 13.81 \\
\hline & 2 & 19 & 14.73 & 0.8395 & 5.7 & 13.96 & 17.33 \\
\hline & 3 & 19 & 9.75 & 0.852 & 8.7 & 7.46 & 10.43 \\
\hline \multirow[t]{3}{*}{$\mathrm{Zn}$} & 1 & 80 & 51.36 & 3.053 & 5.9 & 47.66 & 60.4 \\
\hline & 2 & 139 & 43.04 & 3.547 & 8.2 & 33.3 & 47.58 \\
\hline & 3 & 15 & 28.87 & 3.065 & 10.6 & 22.36 & 32.47 \\
\hline
\end{tabular}

$\mathrm{SD}=$ Standard deviation $. \mathrm{a}=$ only one observation 
similar lines, for $\mathrm{Ca}(\mathrm{CV} \%=16.9$ to $22.8 \%)$. The cluster size can be used to identify the lines with desired level of the nutrients.

This study is one of the early studies on genetic variability of a range of macro and micro-nutrients involving a diverse collection of lentil germplasm including promising breeding lines developed at ICARDA. On average, global pulse consumption is in decline, but lentil consumption is increasing faster than human population growth, making this species ideal for bio-fortification. Thavarajah et al., (2011) presented that lentil has great potential as a fortifiable crop. Seeds of this crop can be utilised as whole food for proving the most of essential nutrients, foliate and anti-nutritional factors (Gupta et al., 2013).

Seed mineral concentrations were highly variable across the accessions reflecting the presumed diversity of these germplasm. This suggests that genotypic variation for macro and micro-nutrient levels in lentil germplasm provides good opportunities for improvement of cultivated lentil. The genotypes viz., ILL 8194 (5800 mg kg-1), ILL 8194 (13600 $\left.\mathrm{mg} \mathrm{kg}^{-1}\right)$, ILL 8105 (1860 $\left.\mathrm{mg} \mathrm{kg}^{-1}\right)$, ILL 7200 (1300 $\mathrm{mg} \mathrm{kg}^{-}$ $\left.{ }^{1}\right)$, ILL $6212\left(3100 \mathrm{mg} \mathrm{kg}^{-1}\right)$, ILL $7547\left(86 \mathrm{mg} \mathrm{kg}^{-1}\right)$, ILL 9886 (20 $\left.\mathrm{mg} \mathrm{kg}^{-1}\right)$, ILL 6459 (9.7 $\left.\mathrm{mg} \mathrm{kg}^{-1}\right)$, ILL 1005 (17 mg $\left.\mathrm{kg}^{-1}\right)$ and ILL $5480\left(60 \mathrm{mg} \mathrm{kg}^{-1}\right)$ were found with highest level of concentrations for $\mathrm{P}, \mathrm{K}, \mathrm{Ca}, \mathrm{Mg}, \mathrm{S}, \mathrm{Fe}, \mathrm{Mn}, \mathrm{B}, \mathrm{Cu}$ and $\mathrm{Zn}$, respectively. A few genotypes showed high concentrations of two or more than two nutrients (ILL8194$\mathrm{P}$ and K; ILL7200- Mg, Ca and P; ILL8105- $\mathrm{Ca}$ and B; ILL590- K and Mn; ILL 6980- Ca and Mg; ILL6211-Mg and Zn; ILL6212- S and K and ILL9892- Fe and Cu). Hence these genotypes showing high concentrations for two or more than two nutrients may be utilised in breeding programs for combined enhancement of nutrient status. The relationship among macro and micro-nutrients provide opportunity to improve two or more nutrients together at a time. The positive correlation of several minerals with each other might be possibly due to common uptake pathways (Table 4). Zn had significant and positive correlation with all the macro and micro-nutrients. Similar results were also reported in lentil by Karaköy et al., 2012. It has been reported that positive relationships between $\mathrm{Zn}$ and $\mathrm{P}$, and $\mathrm{Zn}$ with $\mathrm{Mg}$ may be due to the well-known effect of phytate on binding of $\mathrm{Zn}$ and $\mathrm{Mg}$ in seeds (Marschner, 1995). Positive association of $\mathrm{Zn}$ with other minerals demonstrate that selection of high $\mathrm{Zn}$ concentration accessions may indirectly select for higher levels of other macro and micro-nutrients. Similarly, Mn, $\mathrm{Fe}$ and $\mathrm{Cu}$ had significant and positive correlation with all other macro and micro-nutrients except for Fe-B and $\mathrm{Cu}-\mathrm{B}$ which had negative correlations. In addition, genotypes with high macro and micro-nutrient levels might be suitable for studying the mechanisms of mineral element accumulation and transport. In summary, we identified considerable variation in the macro- and micronutrient contents of lentil germplasm. Our results provide a useful foundation for the development of new cultivars of lentil that have high mineral content.

\section{ACKNOWLEDGEMENT}

We would like to thank Harvest Plus, CRP-A4NH of the CGIAR for financial support to carry out this research. Continued support and encouragement by Drs P. Wolfgang, A. Meike and P. Virk led the authors to carry out the study.

\section{REFERENCES}

Aitchison, J. A. (1986). The Statistical Analysis of Compositional Data. Chapman \& Hall, Florida

FAO(2013):http://faostat.fao.org/

Gupta, D. S., Thavarajah, D., Knutson, P., Thavarajah, P., McGee, R. J., Coyne, C. J. and Kumar, S. (2013). Lentils (Lens culinaris L.), A rich source of folates. Journal of Agricultural and Food Chemistry 61:7794-7799

Karaköy, T., Erdem, H., Baloch, F. S., Toklu, F., Eker, S., Kilian, B. and Özkan, H. (2012). Diversity of macro and micro-nutrients in the seeds of lentil landraces. The Scientific World Journal pp 1-9

Marschner, H. (1995). Mineral Nutrition of Higher Plants, $2^{\text {nd }}$ Edition. Academic Press, London

Payne, R. W. (ed.). (2011). The Guide to GenStat ${ }^{\circledR}$ Release 14. Part 2: Statistics. Hemel Hempstead: VSN International, UK

Singh, D., Chonkar, P. K. and Dwivedi, B. S. (2005). Manual on Soil, Plant and Water Analysis. Westville Publishers, New Delhi.

Thavarajah, D., Thavarajah, P., Wejesuriya, A., Rutzke, M., Glahn, R. P., Combs, Jr. G. F. and Vanderberg, A. (2011). The potential of lentil (Lens culinaris) as a whole food for increased selenium, iron and zinc intake: Preliminary results from a three-year study. Euphytica 180(1): 123-128

Yang, X. E., Chen, W. R. and Feng, Y. (2007). Improving human micronutrient nutrition through bio-fortification in the soil-plant system: China as a case study. Environmental Geochemistry and Health 29: 413-428.

Zarcinas, B. A., Catwright, B. and Spouncer, L. R. (1987). Nitric acid digestion and multi element analysis of plant material by inductively coupled plasm spectrometry. Communications in Soil Science and Plant Analysis 18: 131-146. 